\title{
New In Vitro Studies on the Bioprofile of Genista tenera Antihyperglycemic Extract
}

\author{
Daniela Batista $\cdot$ Pedro L. Falé • Maria L. Serralheiro • \\ Maria E. Araújo · Paulo J. A. Madeira • \\ Carlos Borges • Isabel Torgal • Margarida Goulart • \\ Jorge Justino $\cdot$ Alice Martins $\cdot$ Amélia P. Rauter
}

Received: 1 September 2015/Accepted: 14 October 2015/Published online: 22 October 2015

(C) The Author(s) 2015. This article is published with open access at Springerlink.com

\begin{abstract}
The inhibition of $\alpha$-glucosidase and glucose-6-phosphatase, two enzymes involved in the carbohydrate metabolism, is an important target to control glycaemia on individuals with type 2 diabetes. In this work we report for the first time the inhibition of both enzymes by the antihyperglycemic $n$-butanol extract from Genista tenera (Fabaceae). This extract decreased $\alpha$-glucosidase and glucose-6-phosphatase activities to 0.97 and $80.25 \%$, respectively, being more effective than acarbose, and phlorizin, the positive controls, which reduced enzymes activities only to 17.39 and $96.06 \%$. Once inflammation and oxidative stress are related to diabetic impairments, the anti-inflammatory activity of the extract was also evaluated, through its inhibitory activity over COX-1 enzyme (47.5\% inhibition). Moreover, after induction of oxidative stress by UV radiation, the viability of irradiated rat liver hepatoma cells exposed to the extract was significantly higher $(67.82 \%)$ than that promoted by ascorbic acid, the positive control $(45.05 \%)$. In addition, the stability of the extract under gastrointestinal conditions was evaluated by HPLC-DAD-ESI-MS/MS. Flavonoid diglycosides were identified as the main constituents of the extract, and no alterations in the chemical composition nor in the antioxidant activity were observed after in vitro digestion with artificial gastric and pancreatic juices.
\end{abstract}

Graphical Abstract

Antidiabetic Genista tenera $n$-Butanol Extract

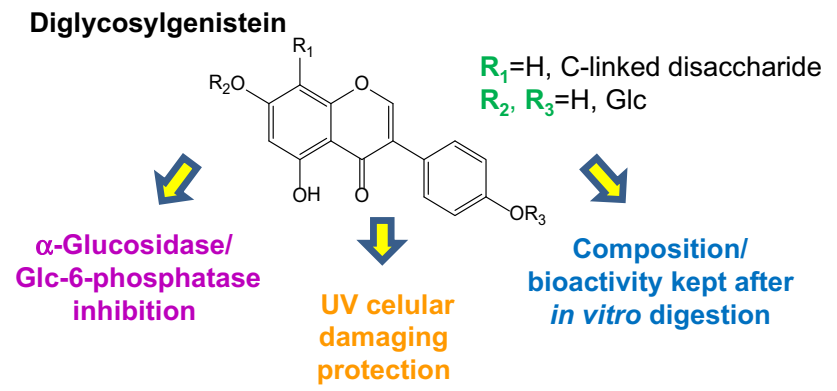

Keywords $\alpha$-Glucosidase inhibition - In vitro digestion $\cdot$ HPLC-DAD-ESI-MS/MS - Antioxidant activity · Flavonoid glycosides

D. Batista · P. L. Falé · M. L. Serralheiro .

M. E. Araújo · P. J. A. Madeira · C. Borges · A. Martins (凹) ·

A. P. Rauter

Centro de Química e Bioquímica, Faculdade de Ciências,

Universidade de Lisboa, Campo Grande, 1749-016 Lisbon,

Portugal

e-mail: aimartins@fc.ul.pt; aprauter@fc.ul.pt
P. L. Falé

Institute of Pharmaceutical Science, King's College London, 150

Stamford Street, London SE1 9NH, UK

I. Torgal · M. Goulart $\cdot$ J. Justino

Escola Superior Agrária de Santarém, Quinta do Galinheiro,

2001-904 Santarém, Portugal 


\section{Introduction}

Type 2 diabetes is a major public health concern, due to the increasing incidence in developed and developing countries. The loss of patient's quality of life, the economic burden associated with direct and indirect costs, the relevant morbidity, and increased mortality reinforce the needs to investigate new treatments and preventive options aiming to control diabetes. There is evidence that hyperglycaemia results in the generation of reactive oxygen species and a link between oxidative stress, inflammatory response and diabetes is now well established [1]. Antioxidants are known to exert beneficial effects in ameliorating the injurious effects of hyperglycaemia in different in vitro and in vivo models [2] and the intake of natural antioxidants, like polyphenols, is able to modulate a number of chronic inflammatory diseases including type 2 diabetes [3]. Amongst the phenolic compounds, flavonoids have been associated with beneficial effects reducing the risk of cancer, diabetes, cardiovascular and brain diseases. These effects are related to their radical scavenging effect along with other possible mechanisms such as anti-inflammatory properties [4]. Epidemiological, in vitro and in vivo studies support the beneficial effect of dietary flavonoids on glucose and lipid homeostasis and a review of the recent findings on the antidiabetic effects of dietary flavonoids, in particularly their cellular and molecular mechanisms of action, has been reported [5]. So, the screening of chemical candidates from herbal medicines is a promising approach for new drugs discovery to the prevention and treatment of diabetes and related complications [6]. Extracts and/or natural molecular entities can act on several mechanisms of type 2 diabetes and enzymes that regulate glucose metabolism are potential targets for controlling glucose balance and thereby blood glucose levels in diabetic patients [7]. A therapeutic approach to prevent hyperglycaemia is to retard the absorption of glucose through the inhibition of alphaglucosidase. Inhibitors can prolong the overall carbohydrate digestion time and cause a reduction in the rate of glucose absorption, blunting the postprandial plasma glucose rise [8]. Glucose-6-phosphatase catalyses the final step of both hepatic gluconeogenesis and glycogenolysis and its inhibition also contributes to the reduction of endogenous glucose production [7].

Genista tenera (Fabaceae) is a medicinal plant used in the island of Madeira, Portugal, to control diabetes. Previous studies have shown that its $n$-butanol extract exhibits a significant antihyperglycemic activity on an animal model with diabetes induced by STZ, and no acute cytotoxicity or genotoxicity to human lymphocytes was observed in an in vitro assay [9]. Aiming to investigate the mechanism of action of this antidiabetic extract we report now the first studies concerning its inhibition of $\alpha$ - glucosidase and glucose-6-phosphatase enzymes. Since oxidative stress and inflammation are also related to diabetes impairments, the effect of the extract on cell viability after UV radiation injury and the inhibition of COX-1 enzyme were also evaluated. Finally, extract stability after in vitro digestion is also here reported for the first time.

\section{Results and Discussion}

\subsection{Effect on Alpha-Glucosidase and Glucose 6-Phosphatase Inhibition}

The inhibitory activity of $G$. tenera $n$-butanol extracts on $\alpha$-glucosidase and glucose-6-phosphatase was evaluated by spectrophotometry-based assays. The inhibition of $\alpha$-glucosidase activity is of crucial importance in delaying absorption of dietary carbohydrates that contribute to postprandial hyperglycaemia in individuals with type 2 diabetes and is one important mechanism for the management of the diabetic condition $[8,10,11]$. The percentage activity of this enzyme, in the presence of G. tenera $n$ butanol extract, compared to the positive and negative controls, is depicted in Fig. 1I. The extract decreased enzyme activity to $0.97 \%$ when compared to the commercial inhibitor acarbose, the positive control, which reduced enzyme activity only up to $17.39 \%$. These results suggest that inhibition of $\alpha$-glucosidase plays an important role in the mechanism of the antihyperglycemic action of G. tenera $n$-butanol extract, thus contributing more effectively to the control of postprandial glycaemia in type 2 diabetes. Glucose-6-phosphatase is the enzyme that catalyses the final step of gluconeogenesis and glycogenolysis and its inhibition is also extremely important to control hyperglycaemia in diabetic patients $[7,12,13]$. The extract showed a tendency to inhibit this enzyme, whose activity decreased to $80.25 \%$, and revealed to be more effective than the positive control phlorizin, for which a remaining enzyme activity of $96.06 \%$ was found, as shown in Fig. 1II.

Flavonoids are reported to inhibit alpha-glucosidase [8] and to alter hepatic gluconeogenic enzymes activity thereby reducing the endogenous glucose production [7], which suggests that the inhibitory activity of the G. tenera $n$-butanol extract can be attributed to its flavonoid composition.

\subsection{Anti-inflammatory Activity}

It is well established that inflammation is also involved in diabetic impairments. In this context, a preliminary evaluation of the anti-inflammatory activity of $G$. tenera butanol extract was assessed by an in vitro assay, involving 


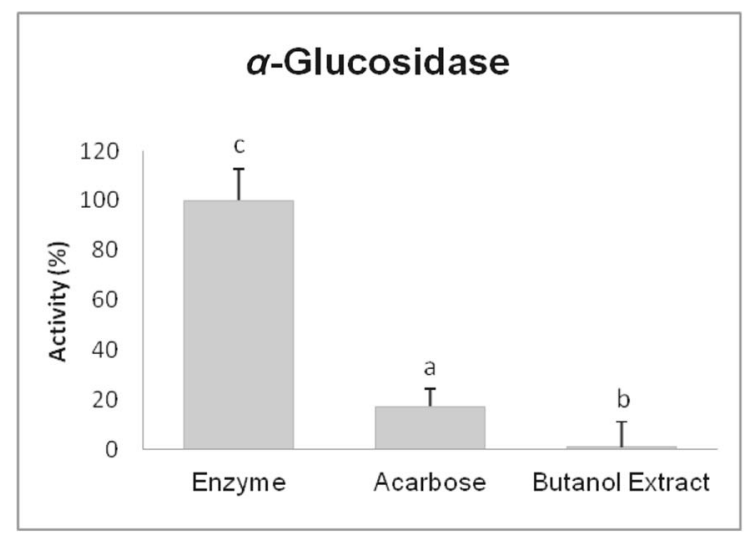

I

Fig. 1 I Activity of rat small intestine $\alpha$-glucosidase in the presence of $G$. tenera $n$-butanol extract. The activity was determined using maltose as substrate and acarbose as positive control. Each value is expressed as mean + standard deviation from a total of five replicates; II Activity of glucose-6-phosphatase from rabbit liver microsomes in the presence of $G$. tenera $n$-butanol, extract. The activity was determined using glucose-6-phosphate as substrate and

the inhibition of cyclooxygenase (COX, or Prostaglandin$\mathrm{H}$ synthase, PGHS), a key enzyme in the synthesis of prostaglandin $\mathrm{H} 2$, which is a precursor for the biosynthesis of prostaglandins (PGs), thromboxanes, and prostacyclins. PGs support the release of further mediators of inflammation and cause the typical symptoms at inflammation sites. Therefore, PGHS has been regarded for a long time as an important target of most non-steroidal anti-inflammatory drugs (NSAIDs). We found that the $n$-butanol extract inhibited COX-1 enzyme ( $47.5 \%$ inhibition at $0.5 \mathrm{mg} /$ $\mathrm{mL}$ ), and presented an $\mathrm{IC}_{50}=291.60 \mu \mathrm{g} / \mathrm{mL}$, which was compared with indomethacin ( $\mathrm{IC}_{50}=60 \mu \mathrm{g} / \mathrm{mL}$ ), a widely used NSAIDs.

\subsection{Effect on Cell Viability}

The influence of the extract on cell viability was also studied using the MTT method. The ability of cells to reduce MTT gives an indication of its integrity and metabolic activity, which in turn may be interpreted as a measure of cell viability. We studied the effect of G. tenera $n$ butanol extract on rat liver hepatoma cells (H-4-II-E), nonirradiated, and irradiated with UV-C radiation. The extract seems to have a positive effect on non-irradiated cells growth, once no statistically significant differences were observed when compared to ascorbic acid, the positive control. The viability of irradiated cells exposed to $G$. tenera $n$-butanol extract was significantly higher $(67.82 \pm 22.36 \%)$ than that of non-treated cells $(38.18 \pm 7.73 \%)$ and that promoted by the ascorbic acid

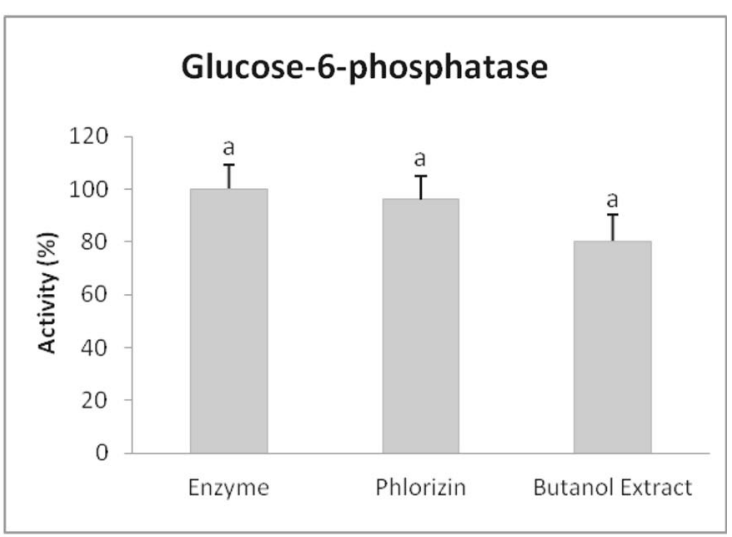

II

phlorizin as positive control. Each value is expressed as mean $+\mathrm{s}$ tandard deviation from a total of 12 tests. For both assays the enzyme activity in the presence of the inhibitor is expressed in percentage of the enzyme activity without inhibitor $(100 \%)$. The same concentrations of extract, acarbose and phlorizin were used, $400 \mathrm{mg} / \mathrm{L}$. Indexes $(a-c)$ indicate statistically significant differences $P<0.05$ analysed by the Tukey a posteriori test

$(45.05 \pm 26.35 \%)$. So, the present study adds further support to the antioxidant properties of $G$. tenera extracts [9] and unveils new potential applications of the plant in long term protection against UV-related cellular damaging.

\subsection{Chemical and Biological Stability After In Vitro Digestion}

In view of a potential use of $G$. tenera extract as a source of nutraceuticals, its stability under gastrointestinal conditions was analysed by HPLC. The extract was submitted to an

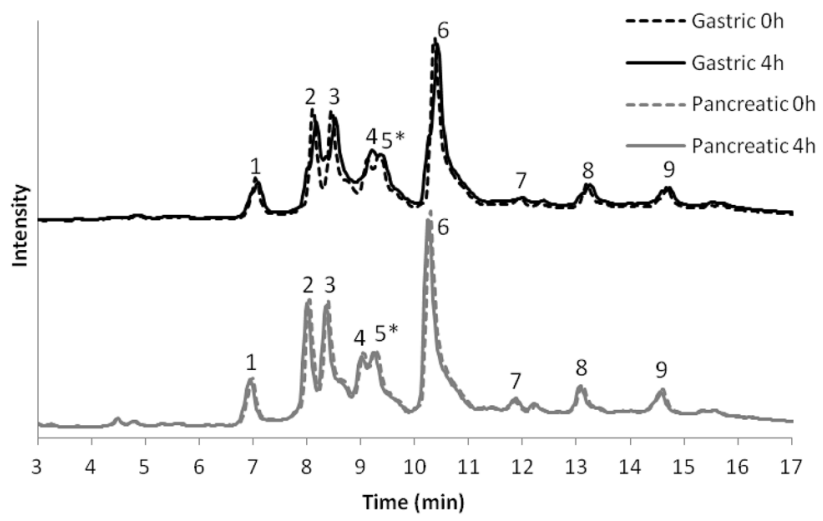

Fig. 2 In vitro gastric and pancreatic digestions of G.tenera nbutanol extract analysed by HPLC-DAD:7-O-glucosyl-8-glucosylgenistein (1), 8-(glucosyloxyglucosyl)genistein (2), 4,7-di- $O$-glucosylgenistein (3), 6,8-diglucosylapigenin (4), unknown (5*), 8-[apiosyl-(1 $\rightarrow 6$ )-glucosyl]genistein (6), 3',7-di- $O$-glucosylluteolin (7), rutin (8), and 3-O-rutinosylisorhamnetin (9) 
Table 1 Putative identification of glycosyl flavonoids from Genista tenera $n$-butanol extract, by HPLC-DAD and HPLC-ESI-MS ${ }^{\mathrm{n}}$

\begin{tabular}{|c|c|c|c|c|c|}
\hline Peak & Rt (min) & $\lambda_{\max }(\mathrm{nm})$ & {$[\mathrm{M}-\mathrm{H}]^{-}$} & $m / z$ Product ions ESI-MS ${ }^{\mathrm{n}}$ (relative abundance, \%) & $\begin{array}{l}\text { Identification (Massbank score } \\
\text { and record) }\end{array}$ \\
\hline 1 & 7.1 & $261,295 \mathrm{sh}$ & 593 & $\begin{array}{l}{\left[\mathrm{MS}^{2} \text { 593]: } 503(2), 473(100)\right.} \\
{\left[\mathrm{MS}^{3} \text { 473]: } 473(100), 445(24), 383(2)\right.} \\
\quad 353(2), 311(12) 310(25), 282(12)\end{array}$ & 7-O-Glucosyl-8-glucosylgenistein \\
\hline 2 & 8.2 & $258,290 \mathrm{sh}$ & 593 & $\begin{array}{l}{\left[\mathrm{MS}^{2} \text { 593]: } 503(<1), 341(5), 311(100), 283(7)\right.} \\
{\left[\mathrm{MS}^{3} \text { 311]: } 311(15), 283(100), 267(1)\right.}\end{array}$ & 8-(Glucosyloxyglucosyl)genistein \\
\hline 3 & 8.7 & $\begin{array}{l}261,271 \mathrm{sh} \\
322 \mathrm{sh}\end{array}$ & $639^{\mathrm{a}}$ & $\begin{array}{l}{\left[\mathrm{MS}^{2} \text { 639]: } 593(10), 591(2), 431(100), 269(2)\right.} \\
{\left[\mathrm{MS}^{3} \text { 431]: } 431(25), 355(4), 323(5), 311(8)\right.} \\
\quad 283(9), 268(100)\end{array}$ & 4,7-Di-O-glucosylgenistein \\
\hline 4 & 9.2 & $\begin{array}{l}272,293 \\
301,314\end{array}$ & 593 & $\begin{array}{l}{\left[\mathrm{MS}^{3} 593\right]: 575(8), 503(30), 473(100)} \\
\quad 455(4), 383(22), 353(39) \\
{\left[\mathrm{MS}^{3} 473\right]: 455(2), 383(17), 353(100)}\end{array}$ & 6,8-Diglucosylapigenin \\
\hline 5 & 9.6 & - & 563 & - & Unknown \\
\hline 6 & 10.5 & $261,290 \mathrm{sh}$ & 563 & $\begin{array}{l}{\left[\mathrm{MS}^{2} 563\right]: 341(6), 311(100), 283(11)} \\
{\left[\mathrm{MS}^{3} \text { 311]: } 311(100), 283(39)\right.}\end{array}$ & $\begin{array}{l}\text { 8-[Apiosyl-(1 } \rightarrow \text { 6)-glucosyl]- } \\
\text { genistein }\end{array}$ \\
\hline 7 & 12.2 & $\begin{array}{l}240,263, \\
322\end{array}$ & 609 & $\begin{array}{l}{\left[\mathrm{MS}^{2} \text { 609]: } 447(100), 285(6)\right.} \\
{\left[\mathrm{MS}^{3} \text { 447]: } 447(2), 285(100)\right.}\end{array}$ & $\begin{array}{l}3^{\prime}, 7 \text {-Di- } O \text {-glucosylluteolin } \\
\quad(0.6758, \text { PR100804) }\end{array}$ \\
\hline 8 & 13.6 & $\begin{array}{l}241,257 \\
294,350\end{array}$ & 609 & $\begin{array}{l}{\left[\mathrm{MS}^{2} \text { 609]: } 447(2), 343(8), 301(100), 271(8),\right.} \\
255(4), 179(3) \\
{\left[\mathrm{MS}^{3} 301\right]: 301(100), 271(42), 255(28)} \\
239(3), 229(3), 211(1), 179(44)\end{array}$ & Rutin (0.4606, PR100804) \\
\hline 9 & 15.1 & $\begin{array}{l}239,257 \\
293,348\end{array}$ & 623 & $\begin{array}{l}{\left[\mathrm{MS}^{2} \text { 623]: } 315(100), 300(19), 271(5), 255(3)\right.} \\
{\left[\mathrm{MS}^{3} \text { 315]: } 315(90), 300(100), 287(5), 272(2)\right.} \\
271 \text { (2) }\end{array}$ & $\begin{array}{l}\text { 3-O-Rutinosylisorhamnetin } \\
\quad(0.4609, \text { PR100658) }\end{array}$ \\
\hline
\end{tabular}

sh shoulder

a This compound ionized as $[\mathrm{M}+\mathrm{HCOO}]^{-}$

in vitro digestion with artificial gastric and pancreatic juices and none of its constituents suffered hydrolysis (Fig. 2). Furthermore, the antioxidant activity was monitored throughout the digestion by the DPPH method. The $\mathrm{IC}_{50}$ value for DPPH extinction was $214.2 \pm 0.3 \mu \mathrm{g} / \mathrm{mL}$ and, after $4 \mathrm{~h}$ digestion with gastric and pancreatic juices, this activity was $101.4 \pm 10.7$ and $112.1 \pm 13.9 \%$ of the initial, respectively. Hence, this extract may pass through the gastrointestinal tract keeping its composition, antioxidant capacity and therefore its biological properties.

\subsection{Chemical Analysis}

Aiming to identify the phytochemical composition of the extract, HPLC-DAD and HPLC-ESI-MS/MS analyses were performed. Nine peaks were detected (Fig. 2), before and after in vitro digestion, and chromatograms showed the same flavonoid profile, which structures are depicted in Fig. 3. The tentative identification of each peak (Table 1) was based on the fragmentation patterns in $\mathrm{MS}^{2}$ and $\mathrm{MS}^{3}$ experiments, UV spectra, and comparison with literature and MassBank database [14]. The $\mathrm{MS}^{2}$ spectrum of the deprotonated molecule of compound $\mathbf{1}$ at $\mathrm{m} / \mathrm{z}, 593$ presents losses of $120 \mathrm{Da}\left({ }^{0,2} \mathrm{X}^{-}\right)$and $90 \mathrm{Da}\left({ }^{0,3} \mathrm{X}^{-}\right)$characteristic of a $C$-glucosyl flavonoid [15], affording the fragment ions at $m / z, 473$ and 503, respectively. Waridel et al. [16] reported that the low abundance of the ${ }^{0,3} \mathrm{X}^{-}$fragment can be correlated with the glycosylation position, namely with glycosylation at $\mathrm{C}-8$, suggesting that the relatively low abundance of ${ }^{0,3} \mathrm{X}^{-}$found for compound $\mathbf{1}$ indicates glycosylation at the $\mathrm{C}-8$ position. From the DAD data, it can be inferred that the aglycone is an isoflavone, with the characteristic maximum wavelength at $261 \mathrm{~nm}$ and a shoulder at $295 \mathrm{~nm}$, while flavones present also an intense band at 330-365 nm. Furthermore, the $\mathrm{MS}^{3}$ spectrum of the ion at $m / z 473$ shows a loss of $162 \mathrm{Da}$, a glucosyl moiety, which is indicative of an $O$-glucoside, suggesting that compound $\mathbf{1}$ is 7-O-glucosyl-8-glucosylgenistein. The deprotonated molecule of compound 2, $\mathrm{m} / \mathrm{z} 593$ loses $252 \mathrm{Da}$ resulting from the combined loss of glucosyl moiety and one ${ }^{0,3} \mathrm{X}$ fragment and $282 \mathrm{Da}$, attributed to a combined loss of glucosyl moiety and ${ }^{0,2} \mathrm{X}$ fragment, affording the ions at $\mathrm{m} / \mathrm{z}, 341$ and 311 , respectively, the latter with $100 \%$ intensity. This behaviour suggests that a glucosylglucoside moiety is $\mathrm{C}-\mathrm{C}$ linked to genistein, in accordance also with the observed UV absorption maxima. 


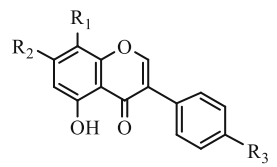

7-O-glucosyl-8-glucosylgenistein

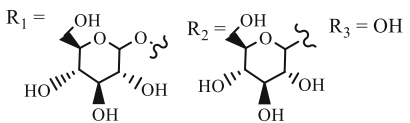

4',7-di-O-glucosylgenistein $\mathrm{R}_{1}=\mathrm{H}, \mathrm{R}_{2}=\mathrm{R}_{2}$

8-(glucosyloxyglucosyl)genistein

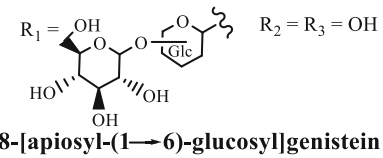

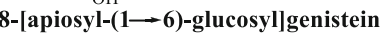
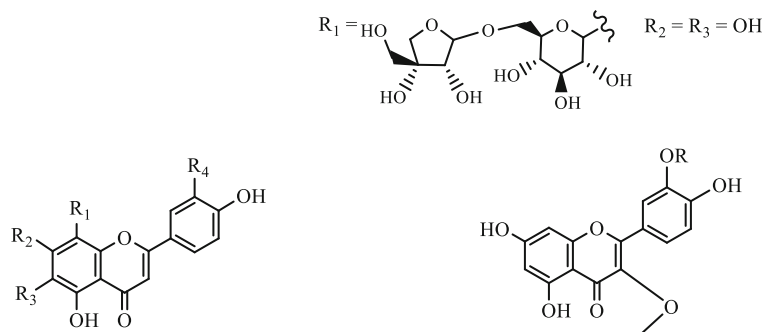

6,8-diglucosylapigenin

$\mathrm{R}_{2}=\mathrm{OH}, \mathrm{R}_{4}=\mathrm{H}$,

$\mathrm{R}_{1}=\mathrm{R}_{3}=$

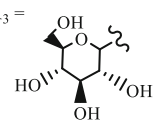

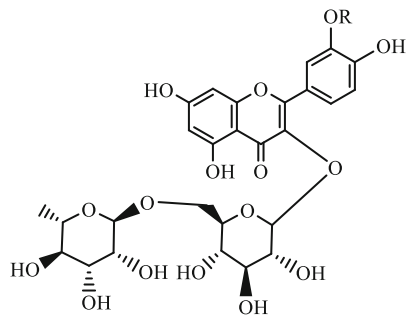

3-O-rutinosylisorhamnetin $\mathrm{R}=\mathrm{CH}_{3}$ rutin $\mathrm{R}=\mathrm{H}$ 3',7-di- $O$-glucosylluteolin

$\mathrm{R}_{1}=\mathrm{R}_{3}=\mathrm{H}$,

$\mathrm{R}_{2}=\mathrm{R}_{4}=\underbrace{\mathrm{OH}}_{\mathrm{OH}} \mathrm{C}_{\mathrm{OH}}^{\mathrm{O}-\xi}$

Fig. 3 Structures of the flavonoids identified in the $n$-butanol extract of $G$. tenera

The loss of $28 \mathrm{Da}(\mathrm{CO})$ observed in $\mathrm{MS}^{3}$ may result from contraction of ring $\mathrm{C}$, which is commonly detected in isoflavones [17, 18]. Two consecutive losses of $162 \mathrm{Da}$ indicate that compound $\mathbf{3}$ is a flavonoid diglucoside, showing an $\mathrm{Y}_{1}{ }^{-}$ion at $\mathrm{m} / \mathrm{z}$ 431. However, this compound ionizes as $[\mathrm{M}+\mathrm{HCOO}]^{-}$turning its assignment more difficult. Nevertheless, the fragmentation pattern is consistent with 4,7-di-O-glucosylgenistein. The formation of $[\mathrm{M}+\mathrm{HCOO}]^{-}$although uncommon, has been reported in the literature for several compounds [19-21]. The DAD data suggest that compound $\mathbf{4}$ could be either a flavone or a flavonol since it exhibits an intense band II (314 nm). In mass spectrometry, $C$-glycosyl flavones suffer cross-ring cleavages of sugar residues yielding ions produced by losses of 90 and $120 \mathrm{Da}$, thus allowing differentiation from $O$-glycosyl flavones with losses of $162 \mathrm{Da}$ for hexose, $146 \mathrm{Da}$ for rhamnose and $132 \mathrm{Da}$ for pentose moieties respectively [22]. The $\mathrm{MS}^{2}$ spectrum of the deprotonated molecule of compound $\mathbf{4}, \mathrm{m} / \mathrm{z} 593$, presents the characteristic losses of a C-glucosyl flavonoid, i.e. the loss of $90 \mathrm{Da}$ affording a ${ }^{0,3} \mathrm{X}^{-}$ion $(\mathrm{m} / \mathrm{z}, 503)$ and $120 \mathrm{Da}$ affording a ${ }^{0,2} \mathbf{X}^{-}$ion $(\mathrm{m} / \mathrm{z} 473)$. The $\mathrm{MS}^{3}$ of the ion at $\mathrm{m} / \mathrm{z} 473$ presents similar losses (90 and $120 \mathrm{Da}$ ), which can be indicative of a di-C-glucosyl flavonoid. A literature survey enabled us to propose compound 4 to be 6,8-diglucosylapigenin, since there is a close agreement between the data available in the literature $[22,23]$ with data acquired by us. The DAD data for compound $\mathbf{6}$ suggests that it is an isoflavone. The loss of $252 \mathrm{Da}$ suggests the presence of a $\mathrm{C}-\mathrm{C}$ linked apiosylglucosyl moiety, affording the ion ${ }^{0,2} \mathrm{X}^{-}$ion at $\mathrm{m} / \mathrm{z} 311$ bearing the apiosyl group. The characteristic loss of $222 \mathrm{Da}$ is also detected by the presence of the ${ }^{0,3} \mathrm{X}^{-}$ion also bearing the apiosyl group at $m / z$ 341. The $\mathrm{MS}^{3}$ of the ion at $\mathrm{m} / \mathrm{z} 311$ shows the loss of $28 \mathrm{Da}$, characteristic of an isoflavone. Interestingly, it was found that retro-DielsAlder fragments, that are observed in flavones, flavanones, flavonols and chalcones were not found in the isoflavones studied, corroborating the results reported by Wang et al. [24] and references cited therein. Hence, the analysis of the data obtained for compound $\mathbf{6}$ suggests the structure of 8-[apiosyl-(1 $\rightarrow 6)$-glucosyl] genistein previously assigned by Peng et al. [25]. The fragments obtained for compounds 7 (3', 7-di- $O$-glucosylluteolin), 8 (rutin), and 9 (3-O-rutinosylisorhamnetin) were identified based on MassBank scores and records (Table 1).

In conclusion, Genista tenera $n$-butanol extract showed a significant inhibition of glucose-6-phosphatase and alphaglucosidase enzymes, which denotes a physiologically important role in the metabolism of carbohydrates, and suggests a possible mechanism of action for its antihyperglycemic activity. Moreover, the anti-inflammatory capacity of the extract, and its protective effect against UVradiation injury are reliable properties that can be attributed to flavonoid diglycosides, the main components of the extract. These components are able to pass the gastrointestinal tract, maintaining their chemical structure and antioxidant activity. The present work adds further support to the previously reported bioactivities of flavonoids from G. tenera extracts and contributes to the valorisation of this plant as a source of bioactive compounds that can be regarded as potential prototypes for the generation of new antidiabetic agents with anti-inflammatory and antioxidant properties.

\section{Experimental}

\subsection{Chemicals and Reagents}

The following reagents used for the evaluation of $\alpha$-glucosidase and glucose-6-phosphatase inhibition were 
purchased from Sigma (St. Louis, MO, USA): rat intestine acetonic fraction, 0.1 M maleate buffer ( $\mathrm{pH}$ 6.9), maltose, diagnostic kit for the determination of glucose (GO), acarbose, glucose-6-phosphate, glucose-6-phosphatase, HEPES (pH 6.5), EDTA, DMSO, and phlorizin.

To evaluate cell viability, the reagents MTT [3-(4,5dimethylthiazol-2-yl)-2,5-diphenyltetrazolium bromide], dimethyl sulfoxide (DMSO), minimum essential medium (MEM), foetal calf serum (FCS), trypsin, phosphate buffered saline(PBS), amphotericin B, penicillin and streptomycin were purchased from Sigma (St. Louis, MO, USA). The H-4-II-E (rat hepatoma) cells were purchased from the European Collection of Cell Cultures.

Cyclooxygenase 1 from sheep (Sigma-Aldrich, Barcelona, Spain) was used to evaluate the anti-inflammatory activity. For the HPLC analysis of the extracts, HPLCgrade methanol and trifluoroacetic acid were purchased from Merck (Darmstadt, Germany). For the antioxidant activity and in vitro digestions with gastric and pancreatic artificial juices, 2,2-diphenyl-1-picrylhydrazyl (DPPH), pepsin and pancreatin were obtained from Sigma-Aldrich (Barcelona, Spain), while potassium phosphate buffer salts were purchased from Merck (Darmstadt, Germany). All reagents used in the present work were of analytical grade.

\subsection{Plant Identification and Extract Preparation}

The plant was collected in Porto Novo, Island of Madeira, and identified by Dr. Roberto Jardim. A voucher specimen (MADJ 10673) is deposited in the Herbarium of Jardim Botânico da Madeira, Funchal, Portugal.

The powdered plant aerial parts $(487.30 \mathrm{~g})$ were exhaustively extracted with ethanol $(3 \times 2.5 \mathrm{~L})$ at room temperature. The ethanol solution was filtered (Whatman no. 4) and concentrated to dryness in a rotary evaporator at $40{ }^{\circ} \mathrm{C}$ and low pressure, giving a crude extract $(62.19 \mathrm{~g})$ to which hot $\left(80-90{ }^{\circ} \mathrm{C}\right)$ distilled water $(500 \mathrm{~mL})$ was added. The aqueous fraction was then filtered and extracted sequentially by partition with diethyl ether $(3 \times 500 \mathrm{~mL})$, ethyl acetate $(3 \times 500 \mathrm{~mL})$ and $n$-butanol $(3 \times 500 \mathrm{~mL})$. Solvents were evaporated under vacuum to give the diethyl ether $(1.23 \mathrm{~g})$, ethyl acetate $(5.19 \mathrm{~g})$, and $n$-butanol $(5.16 \mathrm{~g})$ dried extracts.

\subsection{Enzyme Inhibition Assays}

\subsection{1 $\alpha$-Glucosidase Inhibition}

Enzyme solutions were prepared using rat intestinal acetone powder as the source of $\alpha$-glucosidase. Rat intestinal acetone powder $(50 \mathrm{mg})$ was homogenized with maleate buffer $0.1 \mathrm{M}, \quad \mathrm{pH} \quad 6.9(10 \mathrm{~mL})$ and centrifuged at $6000 \times g$ for $20 \mathrm{~min}$ at $4{ }^{\circ} \mathrm{C}$. The supernatant obtained was used as the enzyme solution for the $\alpha$-glucosidase reaction. Before starting the test, extract samples were dissolved in dimethyl sulfoxide (DMSO) at a concentration of $20 \mathrm{mg} /$ $\mathrm{mL}$. Then, each sample $(10 \mu \mathrm{L})$ was diluted with maleate buffer $0.1 \mathrm{M}$, pH $6.9(90 \mu \mathrm{L})$. Experimental procedure for $\alpha$-glucosidase inhibition was conducted according to the method of Mai et al. [11] with some modifications. Enzyme solution $(50 \mu \mathrm{L})$ was pre-incubated with the extract solution $(50 \mu \mathrm{L})$ and maleate buffer $0.1 \mathrm{M}, \mathrm{pH} 6.9(100 \mu \mathrm{L})$ at $37^{\circ} \mathrm{C}$ for $10 \mathrm{~min}$, and then the enzyme reaction was started by adding maltose substrate solution $(50 \mu \mathrm{L}, 1 \% \mathrm{w} / \mathrm{v}$ in maleate buffer $0.1 \mathrm{M}, \mathrm{pH}$ 6.9). The enzymatic reaction was allowed to proceed at $37^{\circ} \mathrm{C}$ for $10 \mathrm{~min}$, and then stopped by heating at $100{ }^{\circ} \mathrm{C}$ for $5 \mathrm{~min}$. The reaction mixture was kept in ice bath. The generated glucose was measured with a commercial glucose assay kit (GO) at $540 \mathrm{~nm}$, in a Hitachi U-2000 spectrophotometer. A negative control was run with maleate buffer $0.1 \mathrm{M}, \mathrm{pH} 6.9(150 \mu \mathrm{L})$ in the absence of the extract. For blank determination, the enzyme solution was replaced by maleate buffer $0.1 \mathrm{M}, \mathrm{pH}$ $6.9(50 \mu \mathrm{L})$, and the same procedure as described above was carried out. Acarbose was used as a reference compound and tested at the some concentration of the extract (400 mg/L). A total of five separate trials were carried out. The $\alpha$-glucosidase activity is expressed in percentage of the activity of the free enzyme.

\subsubsection{Glucose-6-Phosphatase Inhibition}

Enzyme solution was prepared with rabbit liver microsomes as a source of glucose-6-phosphatase. This solution was prepared according to the method of Marccuci et al. [26] cited by Estrada et al. [13]. Briefly, microsomal protein $(16.74 \mathrm{mg})$ was homogenized with HEPES $5 \mathrm{mM}$, pH $6.5(0.837 \mathrm{~mL})$, sucrose $(0.25 \mathrm{mM})$ and $\mathrm{MgCl}_{2}(1 \mathrm{mM})$ and frozen at $-80{ }^{\circ} \mathrm{C}$ until use. Before starting the test, extract samples were dissolved in dimethyl sulfoxide (DMSO) at a concentration of $20 \mathrm{mg} / \mathrm{mL}$. Then, each sample $(40 \mu \mathrm{L})$ was diluted with HEPES $16 \mathrm{mM}$, pH 6.5 $(60 \mu \mathrm{L})$. Experimental procedure for glucose-6-phosphatase was conducted according to the method described in Estrada et al. [13], with some modifications. In brief, phlorizin $(5.5 \mu \mathrm{L})$ and extracts $(5 \mu \mathrm{L})$ were previously incubated with the enzyme $(2.5 \mu \mathrm{L})$ at $37{ }^{\circ} \mathrm{C}$ for $40 \mathrm{~min}$ and G-6-P solution was added to start the reaction. The glucose-6-phosphatase assay was carried out in a final volume of $100 \mu \mathrm{L}$, with glucose-6-phosphate $(5 \mathrm{mM})$, EDTA $(2 \mathrm{mM})$, HEPES, pH $6.5(16 \mathrm{mM})$ and the enzyme mixture. The reaction was carried out at $37{ }^{\circ} \mathrm{C}$ for $60 \mathrm{~min}$, without shaking, and was stopped by the addition of $1 \mathrm{~mL}$ of ammonium molybdate $(0.28 \%)$, SDS $(1.11 \%)$ and ascorbic acid $(1.11 \%)$ in sulphuric acid $(0.33 \mathrm{M})$. The reaction was incubated at $47^{\circ} \mathrm{C}$ for $20 \mathrm{~min}$ and the 
absorption at $820 \mathrm{~nm}$ was recorded in a Hitachi U-2000 spectrophotometer. The final concentration of DMSO in experimental assays was $2 \%$. Phlorizin was dissolved in DMSO (10\%) and used as positive control in the same concentration as the extracts $(400 \mathrm{mg} / \mathrm{L})$. A total of twelve separate trials was carried out. The glucose-6-phosphatase activity is expressed in percentage of the activity of the free enzyme.

\subsubsection{COX-1 Inhibition}

COX-1 (EC 1.14.99.1) activity was measured by following spectrophotometrically at $611 \mathrm{~nm}$ the oxidation of TMPD with arachidonic acid. This assay was performed as described in [27], with some modifications. Briefly, to Tris- $\mathrm{HCl}$ buffer $100 \mathrm{mM}$, pH $8(1000 \mu \mathrm{L}) \mathrm{COX}-1$ enzyme (200 units dissolved in Tris- $\mathrm{HCl}$ buffer, $50 \mu \mathrm{L}$ ) was added and the cofactor of hematin dissolved in Tris- $\mathrm{HCl}$ buffer $(100 \mu \mathrm{L}$, $3 \mu \mathrm{M}$ in the assay). After $5 \mathrm{~min}$, the enzyme was reconstituted and then a solution of plant extract or a standard inhibitor in DMSO $(50 \mu \mathrm{L})$ and pure DMSO $(50 \mu \mathrm{L})$ were added and pre-incubated for $3 \mathrm{~min}$ at $25^{\circ} \mathrm{C}$. After the incubation time has expired, TMPD dissolved in Tris- $\mathrm{HCl}$ buffer (200 $\mu \mathrm{L}, 100 \mu \mathrm{M}$ in the assay) was added. The reaction was initiated by the addition of arachidonic acid dissolved in DMSO (50 $\mu \mathrm{L}, 100 \mu \mathrm{M}$ in the assay) to the enzyme/extract mixture and contents were mixed immediately. The initial velocity of the reaction was measured following the oxidation reaction of TMPD at $611 \mathrm{~nm}$ for $30 \mathrm{~s}$. The inhibition $\%$ was calculated as follows:

$I(\%)=100-\left(V_{i \text { with inhibitor }} / V_{i \text { with out inhibitor }}\right) \times 100$

where $V_{i}$ with inhibitor is the initial velocity observed at different inhibitor concentrations and $V_{i}$ without inhibitor is the velocity observed for enzyme samples pre-incubated for the same time with inhibitor free in $\mathrm{DMSO}$. $\mathrm{IC}_{50}$ values were determined by regression analysis.

\subsection{Cell Viability Assay}

Cell viability was studied by the MTT [3-(4,5dimethylthiazol-2-yl)-2,5-diphenyltetrazolium bromide] method. The test described below is adapted to be used with cell cultures in growth phase.

\subsubsection{Cell Culture}

The H-4-II-E cells were seeded into tissue culture flasks of $75 \mathrm{~cm}^{2}$ in MEM medium supplemented with $10 \%$ FCS and $1 \%$ antibiotics containing penicillin $(10000 \mathrm{U} / \mathrm{mL})$ and streptomycin $(10 \mathrm{mg} / \mathrm{mL})$ and also $0.1 \%$ antifungal, amphotericin B $(250 \mathrm{mg} / \mathrm{mL})$. The cells have multiplied freely to $80-90 \%$ confluence at $37{ }^{\circ} \mathrm{C}$ in a humidified atmosphere of $10 \% \mathrm{CO}_{2}$ (incubation chamber Shel Lab $\mathrm{CO}_{2}$ Series). The medium was changed every 3 days. When the cultures were 80-90 \% confluent, H-4-II-E cells were washed with PBS $(10 \mathrm{~mL})$, detached with trypsin ( $1 \mathrm{~mL})$, counted and suspended in MEM medium to be seeded in 96-well plates at a density of $5 \times 10^{4}$ cells $/ \mathrm{mL}$. Assays were performed in a laminar flow camera with biosafety class II A/B3 (Steril Gard-Baker Company). Before starting the test, samples were dissolved in DMSO, at a concentration of $20 \mathrm{mg} / \mathrm{mL}$, and at least five separate trials were made.

\subsubsection{MTT Assay}

MTT assay was performed according to INVITTOX Method N. 17 for basal cytotoxicity (ECVAM) [28]. Exponentially growing cells (H-4-II-E) were trypsinized and suspended in fresh media (MEM supplemented with $10 \%$ fetal bovine serum and $100 \mathrm{U} / \mathrm{mL}$ penicillin, and $100 \mathrm{mg} / \mathrm{mL}$ streptomycin) at a density of $5 \times 10^{4}$ cells $/ \mathrm{mL}$, and this cell suspension $(100 \mu \mathrm{L})$ was plated on to each well of a $96-w e l l$ plate. Cells were incubated at $37{ }^{\circ} \mathrm{C}, 5 \% \mathrm{CO}_{2}$ humidified incubator for $24 \mathrm{~h}$, after which the $n$-butanol extract and ascorbic acid (400 mg/L), the positive control, and DMSO, the negative control, were added. The cells were placed in the incubator for $1 \mathrm{~h}$ and then, half of the plates were exposed to UV-C radiation $(\lambda=257.7 \mathrm{~nm}$, Philips TUV G15T8 UVC lamp) for $5 \mathrm{~min}$. Cells were further incubated until a total of $48 \mathrm{~h}$ and then MTT (10 $\mu \mathrm{L}, 10 \mathrm{mg} / \mathrm{mL})$ was added to each well. After $4 \mathrm{~h}$ incubation at $37{ }^{\circ} \mathrm{C}$ the medium was removed and the wells were washed with cold $\left(5^{\circ} \mathrm{C}\right)$ PBS $(100 \mu \mathrm{L})$.The formazan crystals were solubilized by adding DMSO $(100 \mu \mathrm{L})$ to each well and placing the plates in an orbital shaker for $20 \mathrm{~min}$. Colorimetric reading was done in a microplate reader (Beijing Perlong New Technology DNM9602) at 492 and $630 \mathrm{~nm}$ (reference $\lambda$ ). The viability is expressed as an average percentage of metabolically viable cells in each group compared to control cells. Results are averages from five separate assays.

\subsection{In Vitro Digestion}

The gastrointestinal digestion of the plant extract was simulated in vitro with artificial gastric and pancreatic juices using the method described by Falé et al. [19], and the chemical composition of the digested extract was analysed by HPLC-DAD while the remaining antioxidant activity was measured by the DPPH method.

\subsubsection{In Vitro Metabolism by the Gastric Juice}

Gastric juice $(2.5 \mathrm{~mL})$ was added to the extract solution $(5 \mathrm{mg} / \mathrm{mL})$ in water $(2.5 \mathrm{~mL})$. The mixture was incubated 
at $37{ }^{\circ} \mathrm{C}$ for $4 \mathrm{~h}$. Samples $(100 \mu \mathrm{L})$ were taken hourly, added to ice-cold methanol $(900 \mu \mathrm{L})$ and analysed by HPLC. The gastric juice $(100 \mathrm{~mL})$ consisted of pepsin (320 mg) and $\mathrm{NaCl}(200 \mathrm{mg})$, and the $\mathrm{pH}$ was set to 1.2 with concentrated $\mathrm{HCl}$. Assays were done in triplicate.

\subsubsection{In Vitro Metabolism by the Pancreatic Juice}

Pancreatic juice $(2.5 \mathrm{~mL})$ was added to the extract solution $(10 \mathrm{mg} / \mathrm{mL})$ in water $(2.5 \mathrm{~mL})$. The mixture was incubated at $37^{\circ} \mathrm{C}$ for $4 \mathrm{~h}$. Samples $(100 \mu \mathrm{L})$ were taken hourly, added to ice-cold methanol $(900 \mu \mathrm{L})$ and centrifuged for $5 \mathrm{~min}$ at $5000 \times g$. The supernatant was analysed by HPLC. The pancreatic juice consisted of pancreatin $(250 \mathrm{mg})$ in potassium-phosphate buffer $50 \mathrm{mM}, \mathrm{pH} 8(10 \mathrm{~mL})$. Assays were done in triplicate. Samples $(200 \mu \mathrm{L})$ were taken at the same time, centrifuged $5 \mathrm{~min}$ at $5000 \times g$ and the supernatant was analysed for antioxidant activity, against a blank with water instead of plant extract. Assays were done in triplicate and the concentration of the extract in the digestions varied according to the $\mathrm{IC}_{50}$ values for antioxidant activity.

\subsection{Antioxidant Activity}

Antioxidant activity was evaluated by the DPPH method. To a solution of DPPH $(2.5 \mathrm{~mL}, 0.002 \%$ in methanol), $25 \mu \mathrm{L}$ of plant extract $(100-300 \mu \mathrm{g} / \mathrm{mL}$ in the cuvette) were added. The mixture was incubated for $30 \mathrm{~min}$ at room temperature. The absorbance was measured at $517 \mathrm{~nm}$ against a corresponding blank. The antioxidant activity was calculated as follows:

$\mathrm{AA}(\%)=\left(\mathrm{A}_{\mathrm{DPPH}}-\mathrm{A}_{\text {Sample }} / \mathrm{A}_{\mathrm{DPPH}}\right) \times 100$

where $\mathrm{AA}$ is the antioxidant activity, $\mathrm{A}_{\mathrm{DPPH}}$ is the absorption of the DPPH solution against the blank, $\mathrm{A}_{\text {Sample }}$ is the absorption of the sample against the blank. The tests were carried out in triplicate and the extract concentration providing $50 \%$ of antioxidant activity $\left(\mathrm{IC}_{50}\right)$ was obtained by regression analysis.

\subsection{Phytochemical Analysis}

HPLC analysis was carried out in an Elite LaChrom $^{\circledR}$ VWR Hitachi Liquid Chromatograph equipped with a Column Oven L-2300 and Diode Array Detector L-2455 (VWR, USA). A column LiChroCART ${ }^{\circledR}$ 250-4 LiChrospher $^{\circledR} 100$ RP-8 $(5 \mu \mathrm{m})$ from Merck (Darmstadt, Germany) was used. The extract was analysed by injecting the sample ( $25 \mu \mathrm{L}, 1 \mathrm{mg} / \mathrm{mL})$ with an auto injector, and using a gradient composed of solution A (0.05\% trifluoroacetic acid), and solution $\mathrm{B}$ (methanol) as follows: $0 \mathrm{~min}, 80 \%$ A, $20 \% \mathrm{~B} ; 20 \min 20 \% \mathrm{~A}, 80 \% \mathrm{~B} ; 25 \mathrm{~min}, 20 \% \mathrm{~A}$, $80 \% \mathrm{~B}$. The flow was $1 \mathrm{~mL} / \mathrm{min}$, and the detection was carried out between 200 and $500 \mathrm{~nm}$ with a diode array detector.

LC-MS and LC-MS ${ }^{\mathrm{n}}$ analysis were carried out on a liquid chromatograph Surveyor Plus Modular LC system connected to a LCQ Duo ion trap mass spectrometer equipped with an electrospray ionisation (ESI) source, from Thermo Scientific (Bremen, Germany). The column used was a LiChroCART ${ }^{\circledR}$ 250-4 LiChrospher $^{\circledR} 100$ RP-8 $(5 \mu \mathrm{m})$ column (Merck, Darmstadt, Germany). The extract was analysed by injection of the sample $(25 \mu \mathrm{L}, 10 \mathrm{mg} /$ $\mathrm{mL}$ ) and using a linear gradient composed of solution A (1.0\% formic acid), and solution $\mathrm{B}$ (methanol) as follows: 0 min, $70 \%$ A, $30 \%$ B; $20 \min 20 \%$ A, $80 \%$ B; 25 min, $20 \% \mathrm{~A}, 80 \% \mathrm{~B}$. The mass spectrometer was operated in both positive and negative ion modes in the range $\mathrm{m} / \mathrm{z}$ 120-1000 and the parameters were adjusted in order to optimize the signal-to-noise ratios $(\mathrm{S} / \mathrm{N})$ for the ions of interest. Briefly, the nebulizing and auxiliary gas (nitrogen) flow rates were 40 and 20 (arbitrary units) and the capillary temperature was set to $250{ }^{\circ} \mathrm{C}$. Collision induced dissociation (CID) experiments were performed by isolating the ions within the ion trap and accelerating them in order to suffer multiple collisions with the background gas present in the ion trap (helium) using a data dependent acquisition mode. The ions of interest were activated by applying a percentage of a supplementary a.c. potential in the range of $0.75-1.75 \mathrm{Vp}-\mathrm{p}$ (peak-to-peak) to the end cap electrodes of the ion trap at the resonance frequency of the selected ion (referred to as the normalized collision energy, NCE). The injection times were $50 \mathrm{~ms}$ in a full scan and $200 \mathrm{~ms}$ in a MS/MS scan. Xcalibur ${ }^{\mathrm{TM}}$ software from Thermo Scientific was used to acquire and to process the data.

The identification of some extract constituents was performed using the MassBank database (freely available at http://www.massbank.eu/MassBank/).

Acknowledgments The authors gratefully acknowledge Fundação para a Ciência e a Tecnologia for financial support of the projects PTDC/QUI/67165/2006 and PEst-OE/QUI/UI0612/2013. The authors also thank the European Commission for approval of the INOVAFUNAGEING commitment and the support of the project "PERsonalised ICT supported Service for Independent Living and Active Ageing", FP7-ICT-2013-10, Project Nr. 610359, 2013-2016.The collaboration of the staff from the Herbarium of Jardim Botânico da Madeira, for providing plant material, is also acknowledged.

\section{Compliance with Ethical Standards}

Conflict of interest The authors declare no conflict of interest.

Open Access This article is distributed under the terms of the Creative Commons Attribution 4.0 International License (http:// creativecommons.org/licenses/by/4.0/), which permits unrestricted use, distribution, and reproduction in any medium, provided you give appropriate credit to the original author(s) and the source, provide a link to the Creative Commons license, and indicate if changes were made. 


\section{References}

1. E. Nicolle, F. Souard, P. Faure, A. Boumendjel, Curr. Med. Chem. 18, 2661-2672 (2011)

2. A. Dey, J. Lakshmanan, Food Funct. 4, 1148-1184 (2013)

3. K. Kawaguchi, T. Matsumoto, Y. Kumazawa, Curr. Top. Med. Chem. 11, 1767-1779 (2011)

4. G.B. Bubols, D.D. Vianna, A. Medina-Remon, G. von Poser, R.M. Lamuela-Raventos, V.L. Eifler-Lima, S.C. Garcia, MiniRev. Med. Chem. 13, 318-334 (2013)

5. P.V.A. Babu, D.M. Liu, E.R. Gilbert, J. Nutr. Biochem. 24, 1777-1789 (2013)

6. R. Singh, N. Kaur, L. Kishore, G.K. Gupta, J. Ethnopharmacol. 150, 51-70 (2013)

7. G.S. Prasath, S.I. Pillai, S.P. Subramanian, Eur. J. Pharmacol. 740, 248-254 (2014)

8. W. Jiang, H. Kan, P. Li, S. Liu, Z. Liu, Anal. Methods 7, 123-128 (2015)

9. A.P. Rauter, A. Martins, R. Lopes, J. Ferreira, M.L.M. Serralheiro, M.E. Araújo, C. Borges, J. Justino, F.V. Silva, M. Goulart, J. Thomas-Oates, J.A. Rodrigues, E. Edwards, J.P. Noronha, R. Pinto, H. Mota-Filipe, J. Ethnopharmacol. 122, 384-393 (2009)

10. R. Tundis, M.R. Loizzo, F. Menichini, Mini-Rev. Med. Chem. 10, 1-14 (2010)

11. T.T. Mai, N.N. Thu, P.G. Tien, N.V. Chuyen, J. Nutr. Sci. Vitaminol. 53, 267-276 (2007)

12. P.S.M. Prince, N. Kamalakkannan, J. Biochem. Mol. Toxicol. 20, 96-102 (2006)

13. O. Estrada, M. Hasegawa, F. Gonzalez-Mujíca, N. Motta, E. Perdomo, A. Solorzano, J. Méndez, B. Méndez, G. Zea, Phytother. Res. 19, 859-863 (2005)

14. H. Horai, M. Arita, S. Kanaya, Y. Nihei, T. Ikeda, K. Suwa, Y. Ojima, K. Tanaka, S. Tanaka, K. Aoshima, Y. Oda, Y. Kakazu, M. Kusano, T. Tohge, F. Matsuda, Y. Sawada, M.Y. Hirai, H. Nakanishi, K. Ikeda, N. Akimoto, T. Maoka, H. Takahashi, T.
Ara, N. Sakurai, H. Suzuki, D. Shibata, S. Neumann, T. Iida, K. Tanaka, K. Funatsu, F. Matsuura, T. Soga, R. Taguchi, K. Saito, T. Nishioka, MassBank: a public repository for sharing mass spectral data for life sciences. J. Mass Spectrom. 45, 703-714 (2010)

15. K. Ablajan, J. Mass Spectrom. 46, 77-84 (2011)

16. P. Waridel, J.L. Wolfender, K. Ndjoko, K.R. Hobby, H.J. Major, K. Hostettmann, J. Chromatogr. A 926, 29-41 (2001)

17. R. Simons, J.P. Vincken, M.C. Bohin, T.F.M. Kuijpers, M.A. Verbruggen, H. Gruppen, Rapid Commun. Mass Spectrom. 25, 55-65 (2011)

18. P.A. Madeira, M.H. Florêncio, C.M. Borges, Rapid Commun. Mass Spectrom. 24, 3432-3440 (2010)

19. P.L. Falé, C. Ferreira, A.M. Rodrigues, P. Cleto, P.J.A. Madeira, M.H. Florêncio, F.N. Frazão, M.L. Serralheiro, J. Med. Plants Res. 20, 1370-1378 (2013)

20. R. Kostiainen, T.J. Kauppila, J. Chromatogr. A 1216, 685-699 (2009)

21. J.P. Rauha, H. Vuorela, R. Kostiainen, J. Mass Spectrom. 36, 1269-1280 (2001)

22. M.J. Simirgiotis, G. Schmeda-Hirschmann, J. Bórquez, E. Kennelly, Molecules 18, 1672-1692 (2013)

23. J. Han, M. Ye, X. Qiao, M. Xu, B.R. Wang, D.A. Guo, J. Pharm. Biomed. Anal. 47, 516-525 (2008)

24. Y. Wang, L. Yang, Y.Q. He, C.H. Wang, E.W. Welbeck, S.W.A. Bligh, Z.T. Wang, Rapid Commun. Mass Spectrom. 22, 1767-1778 (2008)

25. J.B. Peng, H.M. Jia, Y.T. Liu, H.W. Zhang, S. Dong, Z.M. Zou, J. Pharm. Biomed. Anal. 55, 984-995 (2011)

26. O.L. Marcucci, F. González-Mujica, E. Perez-Ayuso, Acta Cient. Venez. 34, 109-117 (1983)

27. N. Amessis-Ouchemoukh, K. Madani, P.L.V. Falé, M.L. Serralheiro, M.E.M. Araújo, Ind. Crop Prod. 53, 6-15 (2014)

28. European Centre for the Validation of Alternative Methods, ECVAM, Invit. Protoc. 17, 1-6 (1990) 